\title{
Helseforskjeller blant nyfødte barn i Oslo
}

\author{
Marit Rognerud og Inger Stensvold \\ Avdeling for epidemiologi og helseovervåking, Klinikk for forebyggende medisin, Ullevål sykehus, 0407 Oslo \\ Korrespondanse til Marit Rognerud Telefon 22119979 Telefax 22119975 E-post marit.rognerud@ulleval.no
}

\begin{abstract}
SAMMENDRAG
Bakgrunn: Oslohelsa presenterte forskjeller i helsetilstand og faktorer som virker inn på denne mellom bydelene i Oslo (jf. Kommunehelsetjenestelovens § 1-4). Sentrale indikatorer på nyfødte barns helse viste store variasjoner mellom bydelene.

Materiale og metode: Økologisk analyse av data fra Medisinsk fødselsregister (1985-96), mål på sosioøkonomisk status (1995) og indikatorer på kvinners røykevaner (1985-88) på bydelsnivå.

Resultater: Bydelsvise forskjeller i lav fødselsvekt og spedbarnsdødelighet var nær knyttet til sosioøkonomiske faktorer på bydelsnivå. Det ble også vist en samvariasjon på bydelsnivå mellom lav fødselsvekt og røykevaner for kvinner 40-42 år. Medfødte misdannelser viste ingen samvariasjon med sosioøkonomiske eller demografiske mål, men det var en sterk samvariasjon mellom medfødte misdannelser hos norske og ikke-vestlige innvandrere på bydelsnivå.

Konklusjon: De foreliggende datasettene gir ikke grunnlag til å trekke noen sikre konklusjoner om årsaker til de observerte forskjellene. Forskjellene er imidlertid betydelige og kunnskap om de viktigste årsakene er avgjørende for å kunne målrette tiltak. Undersøkelsen burde derfor følges opp med andre typer studier med data på individnivå for å komme nærmere en etiologisk forklaring.
\end{abstract}

\section{Rognerud M, Stensvold I. Differences in health among newborns in Oslo. Nor J Epidemiol 1998; 8 (1): 29-35.}

\section{ENGLISH SUMMARY}

Background: «The Oslo health report» presented differences in health and risk factors between the 25 local authorities within the city of Oslo. Large differences in child health were demonstrated.

Materials and methods: Ecological analysis of birth statistics (1985-96), indicators of women's smoking habits (1985-88) and socio-economic measures (1995) in the local authorities.

Results: Differences in low birth weight and infant mortality displayed strong correlation to differences in socio-economic status. The study also showed an association between area differences in low birth weight and smoking habits for women 40-42 years. Differences in malformations were not linked to socioeconomic or demographic measures, but there was a strong link between the level of malformations among Norwegian and non-western newborns in the local authorities.

Discussion: These data do not provide sufficient evidence to draw conclusions about the aetiology of the observed differences. The differences are considerable, however, and knowledge about the most important aetiologic factors is crucial for selecting interventions. Other types of studies using data on the individual level should therefore be conducted.

\section{INNLEDNING}

Dataene fra Medisinsk fødselsregister for perioden 1985-96 som ble presentert i Oslohelsa viste at det var store forskjeller i indikatorer på nyfødte barns helse mellom bydelene i Oslo (1). Indikatorer på nyfødte barns helse som andel med lav fødselsvekt $(<2,5 \mathrm{~kg})$, perinatal dødelighet (antall døde f.o.m. 28. svangerskapsuke til 7. dag etter fødsel pr. 1000 fødte) og spedbarnsdødelighet (antall døde i første leveår pr. 1000 fødte) viste sterke sammenhenger med mål på sosioøkonomisk status på bydelsnivå (1). Det var også store forskjeller mellom bydelene i hyppighet av medfødte misdannelser (diagnostisert innen 7 dager etter fødsel) i perioden 1985-96, men disse forskjellene viste ingen sammenheng med sosioøkonomiske eller demografiske faktorer på bydelsnivå.

I denne artikkelen presenterer vi forholdet mellom flere eksponeringsvariabler og fødselsdataene $\mathrm{i}$ en økologisk studie av bydelene i Oslo. Mulige årsaker til 
de observerte forskjellene blir diskutert og det pekes på noen problemstillinger som bør utredes grundigere bl.a. ved hjelp av data på individnivå.

\section{MATERIALE OG METODE}

\section{Avhengige eksponeringsvariable: Fodselsdata fra Medisinsk fodselsregister}

Materialet består av aggregert fødselsstatistikk for 83.376 barn der mor var registrert bosatt i Oslo ved fødselstidspunkt i perioden 1985-96. Sentrale indikatorer på nyfødte barns helse som lav fødselsvekt (fødselsvekt $<2,5 \mathrm{~kg}$ ), medfødte misdannelser (diagnostisert innen 7 dager etter fødsel) og spedbarnsdødelighet (antall døde i løpet av 1. leveår pr. 1000 fødte, 1985-94) ble koblet til mødrenes etniske opprinnelse og bostedsbydel. Barna ble også delt i to hovedgrupper etter mors etniske opprinnelse: 66.344 norske og 13.404 ikke-vestlige (der mor er første eller annen generasjons innvandrer fra land utenom VestEuropa, USA, Canada, Australia og New Zealand). Det var en økning i andel barn av ikke-vestlig opprinnelse i Oslo fra ca 11\% i 1985 til 20\% i 1996. Det var $7,9 \%$ av barna som hadde ukjent bydelsadresse. Statistisk sentralbyrå, Kongsvinger utførte koblingene.

\section{Uavhengige eksponeringsvariable}

Bydelsvise forskjeller i sosioøkonomisk status er målt som andel med høy inntekt, definert som prosent av befolkningen mellom 30 og 66 år med en årlig inntekt på $250.000 \mathrm{kr}$ eller mer. Som mål på bydelenes sosioøonomiske status gir høy inntekt omtrent den samme gradering mellom bydelene som den noe mer kompliserte sosiale indeksen som er brukt i Oslohelsa $(r=-0,95 ; p<0,001(1))$ bestående av sosiale og demografiske indikatorer som andel lavt utdannede, arbeidsledige, ikke-vestlige innvandrere og enslige forsørgere.

Som et indirekte mål på de bydelsvise forskjellene i bruk av tobakk har vi brukt bydelsdata for kvinners røykevaner som ble samlet inn av Oslo helseråd i forbindelse med «40-åringsundersøkelsene» i 1985-88 $(1,2)$. Materialet består av opplysninger fra 7323 kvinner i 40-årene som besvarte spørsmålene om røykevaner. Disse kvinnene er noe eldre enn gjennomsnittet for de kvinnene som fødte barn i perioden 1985-96. Data fra Omnibus-undersøkelsen som presenteres i Oslohelsa (1) viser imidlertid de samme bydelsvise forskjeller i røykevaner for kvinner 16-80 år som det som kommer fram i 40-åringsundersøkelsen. Resultater fra andre norske $(3,4)$ og utenlandske $(5)$ studier tyder også på at det er betydelige sosiale forskjeller i forbruk av tobakk blant kvinner generelt og gravide kvinner spesielt. I analysene har vi derfor lagt til grunn at det var tilsvarende store bydelsvise forskjeller i røykevanene til kvinnene som fødte barn i perioden 1985-96 som i de nevnte undersøkelsene.
Andel barn av ikke-vestlig opprinnelse og mors gjennomsnittlige alder ved barnets fødsel var også inkludert i datafilen fra Medisinsk fødselsregister. Andel med lav fødselsvekt er brukt både som en risikofaktor (uavhengig variabel) for spedbarnsdødelighet og som et mål på helse (avhengig variabel).

\section{Metode}

Bydelene i Oslo er brukt som enhet $i$ en økologisk analyse. Vi har beregnet Pearsons korrelasjonskoeffisienter for å se på samvariasjonen mellom spedbarnsdødelighet, medfødte misdannelser og lav fødselsvekt og ulike eksponeringsforhold i bydelene. P-verdier er tosidige og et signifikansnivå på $5 \%$ er valgt. Regresjonsanalyse med lav fødselsvekt som avhengig variabel ble benyttet for å studere flere faktorers innflytelse på fødselsresultatene. For å ta hensyn til forskjeller i antall barn i bydelene er det brukt vektet regresjon. Som vekt er benyttet den inverse av den estimerte variansen. Analysene er kjørt i SPSS 7.0 for Windows.

\section{RESULTATER}

\section{Lav fodselsvekt og spedbarnsdodelighet}

Mens spedbarnsdødeligheten i Oslo lå på samme nivå som landet som helhet, var andel barn med lav fødselsvekt noe høyere i Oslo enn i Norge i perioden 1985-96 (tabell 1). I Oslos bydeler varierte andel med lav fødselsvekt fra 4,5\% til 7,5\% (tabell 1, figur 1). De bydelsvise forskjellene i lav fødselsvekt viste en sterk sammenheng med bydelsvise forskjeller i spedbarnsdødelighet (tabell 2). Forskjellene i lav fødselsvekt (figur 1) var knyttet til forskjeller i andel barn av ikkevestlig opprinnelse (figur 2), høy inntekt (figur 3), mors gjennomsnittsalder (figur 4) og mål på sigarettforbruk på bydelsnivå (tabell 2).

Spedbarnsdødeligheten viste signifikante samvariasjoner med lav fødselsvekt, andel ikke-vestlige barn og høy inntekt, men ikke med mors alder og indikatoren for forskjeller i røykevaner (tabell 2).

Ikke-vestlige innvandrere i Oslo hadde en høyere andel barn med lav fødselsvekt enn norske $(7,4 \%$ av ikke-vestlige og 5,6\% av norske; $\mathrm{p}<0,001)$. Fordelingskurven av fødselsvekten var noe venstreforskjøvet og giennomsnittsvekten for alle nyfødte var noe lavere for ikke-vestlige barn i forhold til norske (data ikke vist). Ikke-vestlige innvandrere bor hovedsakelig i bydeler med lav sosioøkonomisk status (1) og barn av ikke-vestlige innvandrere utgjør størst andeler av alle fødte barn i disse bydelene (figur 2).

Det kan se ut som kvinner i Oslo røyker noe mindre enn landsgjennomsnittet $(2,6)$. Variasjonene mellom bydelene er imidlertid svært store (tabell 1).

Mors gjennomsnittsalder ved fødsel er høyere i «høyinntektbydelene» enn i «lavinntektbydelene» (figur 3 og $4, r=0,92 ; p>0,001)$. Andel kvinner over 40 
Fig. 1

Andel barn med lav

fødselsvekt (<2,5 kg) 1985-96

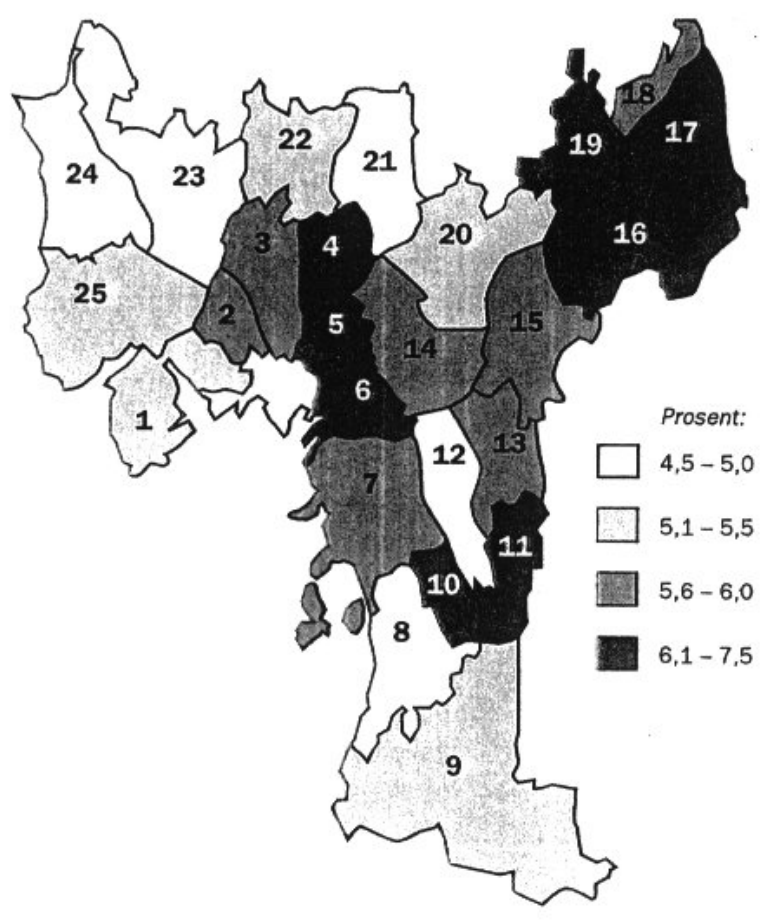

Fig. 3

Andel med hry inntekt (brutto

inntekt >250 000) i 1995

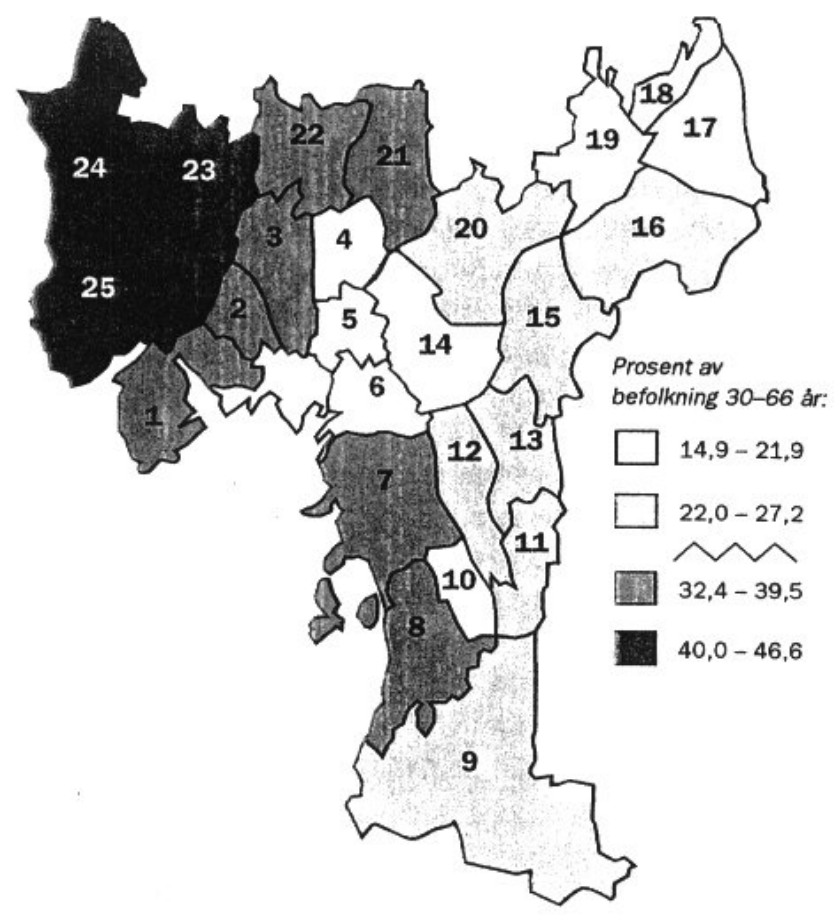

Fig. 2

Andel barn av ikke-vestlig

opprinnelse 1985-96

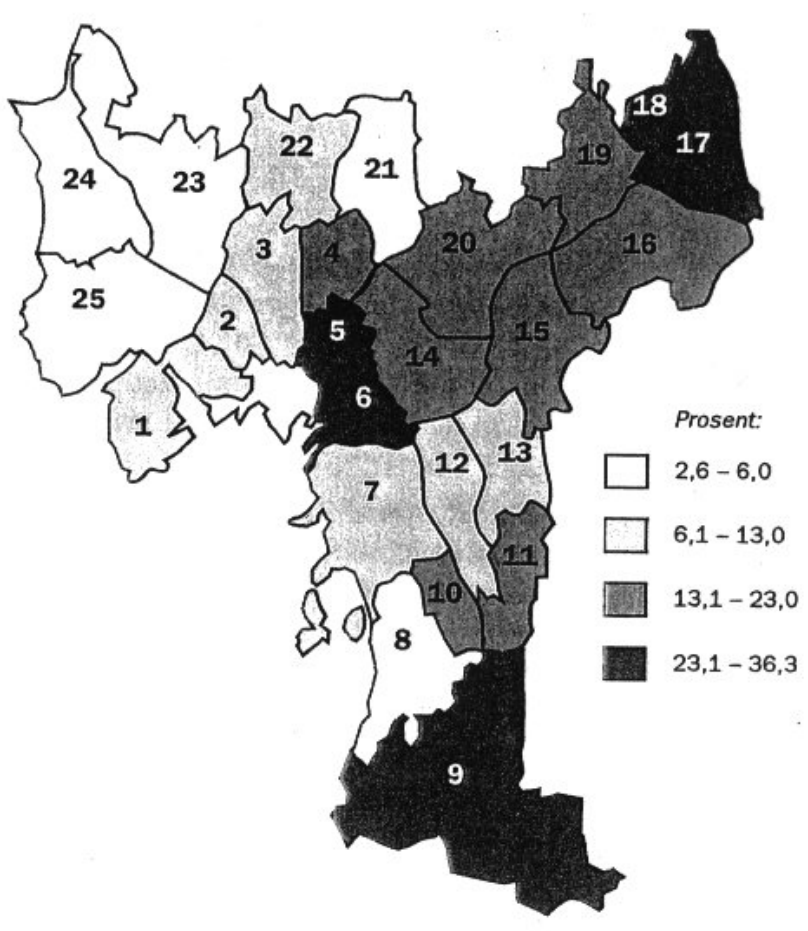

Fig. 4

Mors gjennomsnittlige alder

ved barnets fødsel 1985-96

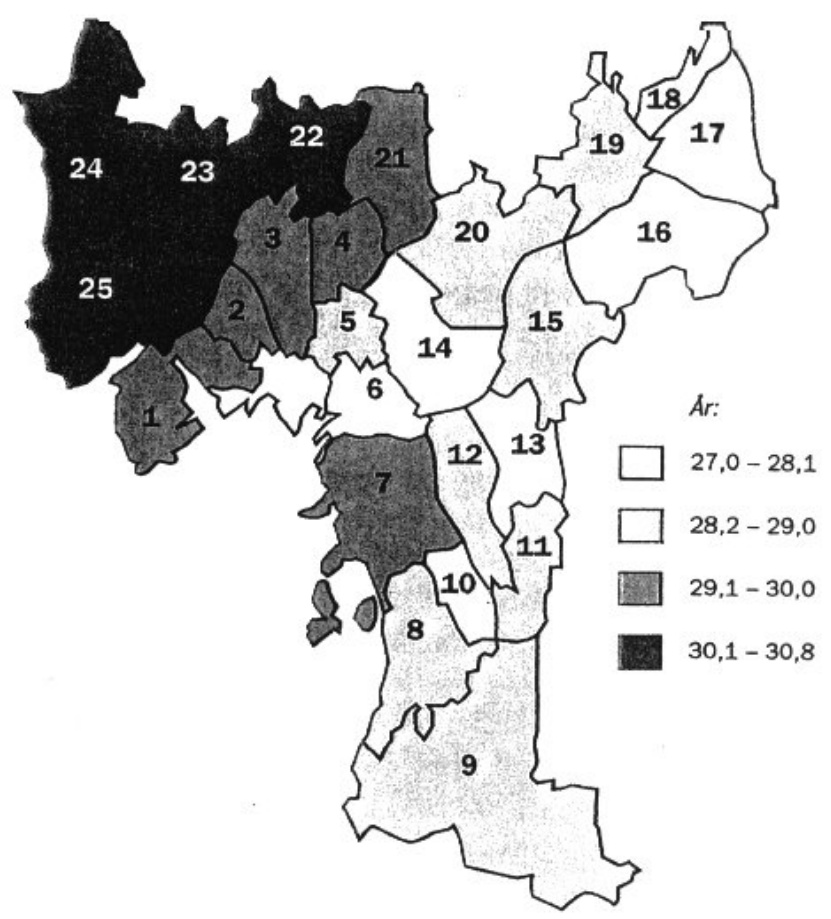


Tabell 1. Forskjeller mellom bydelene, Oslo og landet i de variablene som er brukt i artikkelen.

\begin{tabular}{lrrrrrr}
\hline & Årstall & Max & Min & Ratio & Oslo & Norge \\
\hline Høy inntekt (\%) & 1995 & 46,6 & 14,9 & 3,1 & 30,8 & \\
Mors alder (år) & $1985-96$ & 30,8 & 27,0 & 1,1 & 28,6 & 27,5 \\
Barn av ikke-vestlige (\%) & $1985-96$ & 36,3 & 2,6 & 14,0 & 18,4 & 3,5 \\
Røyking - 40-åringsundersøkelsen (\%) & $1985-88$ & 54,7 & 23,8 & 2,3 & 39,5 & $41^{*}$ \\
Lav fødselsvekt (\%) & $1985-96$ & 7,5 & 4,6 & 1,6 & 5,9 & 5,3 \\
$\quad$ Lav fødselsvekt - norske (\%) & $1985-96$ & 7,7 & 4,5 & 1,7 & 5,6 & \\
Medfødte misdannelser (\%) & $1985-96$ & 6,8 & 2,9 & 2,4 & 4,8 & 3,3 \\
Spedbarnsdødelighet (\%) & $1985-94$ & 9,0 & 3,1 & 2,9 & 6,9 & 6,9 \\
\hline
\end{tabular}

* Beregnet på grunnlag av fremmøtte til 40-åringsundersøkelsene i alle fylker: 13 fylker i 1985-89 og 5 fylker i 1990-92 (6), Oslo i 1985-88 (2).

Tabell 2. Korrelasjon mellom uavhengige og avhengige variabler på bydelsnivå (Pearson’s korrelasjonskoeffisient).

\begin{tabular}{|c|c|c|c|c|c|}
\hline & \multicolumn{3}{|c|}{ Lav fødselsvekt } & \multirow{2}{*}{$\begin{array}{l}\text { Spedbarns- } \\
\text { dødelighet }\end{array}$} & \multirow{2}{*}{$\begin{array}{c}\text { Medfødte } \\
\text { misdannelser }\end{array}$} \\
\hline & Alle & Norske & Ikke-vestlige & & \\
\hline Lav fødselsvekt & & & & $0,51 * *$ & $-0,13$ \\
\hline Røyking (40 år) & $0,60 * *$ & $0,50^{*}$ & 0,12 & 0,36 & 0,26 \\
\hline Barn av ikke-vestlige & $0,74 * *$ & $0,64 * *$ & 0,19 & $0,57 * *$ & $-0,21$ \\
\hline Høy inntekt & $-0,72 * *$ & $-0,63 * *$ & $-0,17$ & $0,42 *$ & 0,15 \\
\hline Mors Alder & $-0,62 * *$ & $-0,54 * *$ & $-0,11$ & $-0,29$ & 0,18 \\
\hline
\end{tabular}

*signifikant på 5 prosent nivå

**signifikant på 1 prosent nivå

år ved fødselstidspunkt varierte fra $0,8 \%$ på Romsås (bydel 18) til 3,8\% på Vinderen (bydel 23). Dessuten viste mors gjennomsnittsalder en sterkt negativt korrelasjon med røykende kvinner $(\mathrm{r}=-0,89 ; \mathrm{p}<0,001)$ og ikke-vestlige barn $(\mathrm{r}=-0,75 ; \mathrm{p}<0,001)$.

Tabell 3 viser at forskjellene i høy inntekt kan forklare 55 prosent av de bydelsvise forskjellene i lav fødselsvekt. Bydelsvise forskjeller i røykevaner og mors alder ser også ut til å være betydelige enkeltfaktorer. Samlet forklart varians i lav fødselsvekt øker imidlertid bare fra 55\% til 56\% ved å inkludere disse faktorene i regresjonsmodellen i tillegg til høy inntekt. Tilsvarende analyser er gjort for gruppene norske og ikke-vestlige hver for seg. Samlet forklart varians i lav fødselsvekt var $48 \%$ for norske og $3 \%$ for ikkevestlige innvandrere.

Tabell 3. Forklart varians i lav fødselsvekt.

\begin{tabular}{lc}
\hline & $\mathrm{R}^{2}$ \\
\hline Høy inntekt & $55 \%$ \\
Mors alder & $44 \%$ \\
Røyking (40 år) & $48 \%$ \\
Samlet & $56 \%$ \\
\hline
\end{tabular}

\section{Medfodte misdannelser}

Medfødte misdannelser ble hyppigere diagnostisert $\mathrm{i}$ Oslo enn i landet som helhet i perioden 1985-96 (tabell 1). I bydelene i Oslo varierte andelen medfødte misdannelser fra 2,9\% til 6,8\% (tabell 1) og alvorlige medfødte misdannelser fra $0,7 \%$ til $1,5 \%$ (1). Tabell 2 viser at det ikke er noen signifikante samvariasjoner mellom medfødte misdannelser og noen av de øvrige variablene. Dette gjelder både totalt og for hver av gruppene norske og ikke-vestlige innvandrere (data ikke vist). Det er imidlertid en sterk sammenheng mellom medfødte misdannelser hos norske og ikkevestlige innvandrere på bydelsnivå i Oslo $(r=0,55$; $\mathrm{p}<0,01)$. Dette tyder på at medfødte misdannelser hos norske og hos ikke-vestlige innvandrere i stor grad opptrer i de samme bydelene.

\section{DISKUSJON}

\section{Bydelsvise forskjeller i lav fodselsvekt og spedbarns- dodelighet}

I denne artikkelen har vi brukt andel med høy inntekt som et mål på bydelenes sosioøkonomiske status. Oslohelsa viser at de bydelsvise forskjellene i høy inntekt 
er knyttet til tilsvarende forskjeller i utdanningsnivå, arbeidsledighet, andel enslige forsørgere, ikke-vestlige innvandrere, livsstilsfaktorer som f.eks. dagligrøyking, vekt og mosjonsvaner samt boligmiljø og arbeidsmiljø (1). Sammenhengene mellom inntekt og helseindikatorer som lav fødselsvekt og spedbarnsdødelighet er derfor komplekse og kan like godt være forårsaket av bydelsvise forskjeller i mors helse og opplysningsnivå, livsstil, bomiljø og arbeidsforhold som i inntekt.

Barn med lav fødselsvekt har økt risiko for spedbarnsdødelighet (7-10), læringsvansker $(11,12)$, luftveislidelser i barneårene $(9,13)$ og utvikling av sykdom som høyt blodtrykk, hjerneslag, diabetes og hjerteinfarkt i voksen alder (14-16). Lav fødselsvekt kan skyldes både intrauterin vekstretardasjon og prematur fødsel. Faktorer som f.eks. tobakksrøyking, høyt blodtrykk, infeksjoner, alkohol, dårlig ernæring og mangelfulle svangerskapstjenester er kjente risikofaktorer for lav fødselsvekt $(7-9,17,18)$. Tobakksrøyking i svangerskapet er antakelig den mest utbredte risikofaktoren i Norge i dag $(3,17)$. Det kan se ut til at kvinner i Oslo røyker noe mindre enn landsgjennomsnittet. Allikevel har Oslo en høyere andel barn med lav fødselsvekt enn landet for øvrig. Det er mulig at ikke-vestlige kvinner i Oslo bidrar til at Oslo har en lavere andel røykende kvinner enn landsgjennomsnittet. I følge primærleger i Oslo røyker ikke-vestlige kvinner svært sjelden. Ikke-vestlige innvandrere utgjør en langt større andel av befolkningen i Oslo enn i landet for øvrig (tabell 1). Hvis det er en lav prosent røykere blant ikke-vestlige kvinner, og ikke-vestlige innvandrere utgjør størst andel av befolkningen i «lavinntektsbydelene» (figur 2 og 3), vil disse bidra til å redusere den sosiale gradienten $\mathrm{i}$ andel dagligrøykere mellom bydelene. Vi finner en sterk samvariasjon på bydelsnivå mellom variabler som røyking, inntekt, mors gjennomsnittsalder og andel ikke-vestlige barn, men med aggregerte data som dette blir det vanskelig å anslå betydningen av enkeltfaktorene. Den høyere (negative) korrelasjonen mellom lav fødselsvekt og høy inntekt enn mellom lav fødselsvekt og røyking kan være et uttrykk for at det også er forskjeller i andre risikofaktorer (som kan knyttes til sosial status) som har betydning for omfanget av lav fødselsvekt på bydelsnivå. Imidlertid er det mulig at de tilgjengelige dataene om 40-årige kvinners røykevaner ikke gjenspeiler de faktiske bydelsforskjellene i tobakksforbruk blant kvinnene som fødte barn i Oslo i perioden 1985-96.

Barn av ikke-vestlige kvinner blir oftere født med lav fødselsvekt enn norske barn selv om det rapporteres om en langt lavere andel røykere blant ikkevestlige kvinner enn blant norske (1). Ikke-vestlige innvandrere har derimot dårligere levekår enn nordmennene i snitt (19). De bor trangere, har lavere utdanning, større problemer med økonomi, høyere arbeidsledighet og de som er yrkesaktive har mer belastende arbeid $(19,20)$. Dette er forhold som kan gi økt risiko for dårlig helse både for mor og barn. Ikke-vestlige kvinner føder dessuten noe oftere barn i tenårene og etter 40-års alderen (data ikke vist) som også kan ha betydning for fødselsresultatene $(7,9)$. Det kan også være at genetiske (etniske) faktorer har betydning for fødselsvekten i og med at gjennomsnittsvekten for alle barn av ikke-vestlig opprinnelse er lavere enn for norske. Imidlertid er også spedbarnsdødeligheten noe høyere blant ikke-vestlige innvandrere (1). Dette kan tyde på at den høyere andelen barn med lav fødselsvekt blant ikke-vestlige innvandrere ikke bare er et utslag av etniske eller genetiske forskjeller i fødselsvekt, men at det også er et uttrykk for dårligere fødselsresultater.

Svangerskapstjenestene er viktige for å forebygge lav fødselsvekt og dødelighet i perinatal- og spedbarnsperioden $(7-9,18)$. Vi vet ikke om ikkevestlige kvinner gjør bruk av svangerskapstjenestene $i$ like stor grad som norske. Det kan være språklige og kulturelle barrierer som gjør at det norske helsevesenet ikke virker like effektivt overfor ikke-vestlige kvinner. For å kunne tilrettelegge tjenestetilbudet til ulike grupper, trengs det mer forskning bl.a. om ikke-vestlige kvinners bruk av og eventuelle barrierer for å bruke helsetjenestetilbud som svangerskapskontroll og helsestasjon, samt utbytte av tjenestene og omfanget av andre risikofaktorer for sykdom hos mor og barn.

Utviklingen av nyfødtmedisinen de senere årene har medført en betydelig reduksjon av den vektspesifikke dødeligheten (8-10). Den sterke sammenhengen vi finner mellom lav fødselsvekt og spedbarnsdødelighet på bydelsnivå i Oslo tyder på at lav fødselsvekt fortsatt er en betydelig risikofaktor for spedbarnsdødelighet. Selv om ikke-vestlige barn gjennomsnittlig hadde en høyere spedbarnsdødelighet enn norske, ser det ut til at mesteparten av overdødeligheten i de østlige bydelene kan tilskrives en høyere spedbarnsdødelighet blant norske i disse bydelene (1). I perioden 1985-94 var det imidlertid bare 475 dødsfall blant spedbarn i Oslo, 339 norske og 113 ikke-vestlige. Dødelighetstallene er derfor forbundet med en stor grad av usikkerhet.

\section{Medfodte misdannelser}

Overhyppigheten av medfødte misdannelser i Oslo i forhold til landet for øvrig kan ha sammenheng med forskjeller i diagnostisk praksis ved sykehusene (Lie Nielsen, Medisinsk fødselsregister, personlig meddelelse). Imidlertid kan forskjeller i diagnostisk praksis neppe forklare de store forskjellene mellom bydelene $\mathrm{i}$ Oslo, i og med at det ikke fremkommer noen sammenheng med sykehussektorene i Oslo. Det er kjent at forekomsten av kromosomdefekter øker betydelig med økende alder hos mor (9). Vi kan imidlertid ikke finne noen sammenheng mellom mors gjennomsnittsalder og medfødte eller alvorlig medfødte misdannelser hverken totalt eller for hver av gruppene norske og ikke-vestlige innvandrere. En mulig årsak til dette kan 
være at selv om gjennomsnittsalderen ved fødsel for hele perioden varierte fra 27,0 år på Romsås (bydel 18) til 30,8 år på Vinderen (bydel 23), var det en relativt liten andel $i$ alle bydelene som fødte barn ved en såpass høy alder at dette ville få vesentlig betydning for det totale omfanget av medfødte misdannelser.

Det foregår også en omfattende screening av alle gravide i forbindelse med ultralydunders $ø$ kelsene i 18 . uke. Kvinner over 38 år får dessuten tilbud om mer omfattende utredning for kromosomdefekter. Et økende antall senaborter kan tyde på at omfanget av selektiv abort av barn med bl.a. misdannelser har økt (21). Dette kan være noe av forklaringen på nedgangen i andel medfødte misdannelser som ble observert i perioden 1985-96 (1). Slike screeningsprogrammer kan også ha bidratt til å redusere effekten av forskjeller i kjente risikofaktorer som f.eks. alder mellom bydelene.

Andelen alvorlige medfødte misdannelser er noe høyere i gruppen ikke-vestlige innvandrere (1). Stoltenberg og Magnus har tidligere vist en høyere andel alvorlige medfødte misdannelser blant pakistanske barn som hadde sammenheng med en høy grad av giftemål mellom nære slektninger (22). Pakistanerne utgjør omlag en firedel av alle ikke-vestlige innvandrere i Oslo (23). Andel barn av ikke-vestlig opprinnelse ser ikke ut til å påvirke hyppigheten av alvorlig medfødte misdannelser på bydelsnivå $\mathrm{i}$ vårt materiale (data ikke vist). Mors alder ved barnets fødsel og andel ikke-vestlige innvandrere er imidlertid variable med høy grad av negativ korrelasjon $(r=-0,65 ; \mathrm{p}<0,01)$ på bydelsnivå. Hvis mors alder ved fødsel har en viss betydning for andel alvorlige medfødte misdannelser, vil denne faktoren virke i motsatt retning og nøytralisere en eventuell effekt av andel ikke-vestlige barn på bydelsnivå. Analyser av data på individnivå har vist at det er en sammenheng mellom medfødte misdannelser, lav fødselsvekt og dødelighet (24). Våre data på bydelsnivå viser imidlertid ikke noen slik sammenheng.

At medfødte misdannelser hos norske og ikkevestlige innvandrere i stor grad opptrer i de samme bydelene, kan tyde på at det finnes lokale miljøfaktorer som har betydning for omfanget av medfødte misdannelser i flere bydeler. Vi finner ikke tegn til noen tidsavgrenset opphopning som kan tyde på utbrudd av lokale epidemier av infeksiøs opprinnelse. For å komme nærmere en etiologisk forklaring, trenger vi mer detaljerte opplysninger på individnivå.

\section{Okologisk analyse}

Økologiske studier kan utføres relativ raskt og enkelt basert på eksisterende datakilder. Man kan studere og sammenlikne store befolkningsgrupper, geografiske forskjeller og utvikling over tid. Dette gjør metoden velegnet til basis-kartlegging og overvåking. I Oslohelsa er det samlet inn en rekke aggregerte data på bydelsnivå i Oslo. Vi kan ikke koble eksponering til helseeffekter hos den enkelte, slik som man kan i studier med individer som observasjonsenheter. Vi kan derfor ikke vite om de individene som opplever helseeffektene er de samme individene som har vært utsatt for risikoeksponering. Alle variablene, både de uavhengige og avhengige, er kontinuerlige variable angitt som gjennomsnittet av populasjonene i bydelene. Analysene i denne artikkelen er først og fremst brukt for å framskaffe en bred oversikt over noen sentrale indikatorer på nyfødte barns helse og kjente risikofaktorer i bydelene i Oslo. Vi har forsøkt å identifisere noen problemområder og generert noen hypoteser som bør utredes nærmere med andre epidemiologiske forskningsmetoder.

\section{KONKLUSJON}

I og med at barn med lav fødselsvekt både er mer utsatt for sykdommer, funksjonsforstyrrelser (7-9,11-16) og dødelighet i perinatal- og spedbarnsperioden, er det ingen god løsning å satse ensidig på teknologisk utvikling av nyfødtmedisinen for å redusere dødeligheten (9). For å bedre helsetilstanden til nyfødte barn i Oslo øst, bør man først og fremst satse på å forebygge lav fødselsvekt. Tiltak som kan øke bruken av og bedre kvaliteten på svangerskapstjenestene - samt heve det generelle kunnskapsnivået til kvinner i fertil alder - er viktige elementer i en slik strategi (9). Det kan være en stor andel dagligrøykere blant norske kvinner i Oslo øst. Økt innsats og systematisk metodeutvikling på tiltak både $\mathrm{i}$ skolen og $\mathrm{i}$ svangerskapsomsorgen $(8,9,17,25)$ kan være en vei å gå. Imidlertid er det som tidligere nevnt betydelige kunnskapshull om de viktigste årsakene til de observerte helseforskjellene og virkninger av ulike tiltak. Det er derfor behov for mer forskning på disse områdene.

Vi vil takke Per Nafstad, Folkehelsa, for å ha bidratt med gode faglige innspill til artikkelen. Videre vil vi takke Medisinsk fødselsregister for god hjelp med dataene.

\section{REFERANSER}

1. Rognerud M, Stensvold I (red.). Oslohelsa. Utredningen om helse, miljø og sosial ulikhet i bydelene. Oslo kommune-Ullevål sykehus, 1998.

2. Jenum AK, Thelle DS, Stensvold I, Hjermann I. Regionale ulikheter i sykdomsrisiko i Oslo. Røyke- og mosjonsvaner, kroppsmasseindeks, blodlipidnivå og blodtrykk blant 40-åringer 1985-88. Tidsskr Nor Lageforen 1998; 118: 23-7. 
3. Nylander G. Røyking og graviditet. Tidsskr Nor Laegeforen 1987; 107: 662-5.

4. Statens tobakkskaderåd. Opp i røyk. Om tobakksrøyk i Norge gjennom 20 år. Oslo: Statens tobakkskaderåd, 1994.

5. Oakley A. Smoking in pregnancy. Smokescreen or risk factor? Towards a materialist analysis. Sociol Health Illness 1989; 11: 311-35.

6. Wøien G, Øyen O, Graff-Iversen S. 22 år med hjerte- og karundersøkelser i norske fylker. Bør vi være tilfreds med den utviklingen risikofaktorene har hatt? Norsk Epidemiologi 1997; 7: 255-66.

7. Backe B, Herland R, Jacobsen G, Nakling J, Tandberg A, Telje J, Øverlie BN. Evaluering av svangerskapomsorgen. Trondheim: Sintef-NIS, rapport 1991:3.

8. California Department of Health Services. Plan for the Maternal \& Child Health: Year 2000 Objectives. California DHS, 1991.

9. Wallace HM, Ryan GJ, Oglesby AC. Maternal and child health practices. Oakland, California: Third Party Publishing Company, 1988.

10. Medisinsk fødselsregister 1967-96. Fødsler i Norge gjennom 30 år. Bergen: Medisinsk fødselsregister, 1997.

11. Sørensen HT, Sabroe S, Oslen J, Rothman KJ, Gillman MW, Fischer P. Birth weight and cognitive functions in young adult life: historical cohort study. BMJ 1997; 315: 401-403.

12. Morgane PJ, et al. Prenatal malnutrition and development of the brain. Neurosci Biobehav Rev 1993; 17: 91128.

13. Nafstad P. Tobacco smoke exposure in early life: Assessment of exposure and health effects. Oslo: Folkehelsa, 1997 (Doktorgrad).

14. Barker DJP. Mothers, babies, and disease in later life. London: BMJ Publishing Group, 1994.

15. Osmond C, Barker DJP, Winter PD, Fall CHD, Simmonds SJ. Early growth and death from cardiovascular disease in women. $B M J$ 1993; 307: 1519-24.

16. Koupilova I, Leon DA, Vågerö D. Can confounding by sociodemographic and behavior factors explain the association between size at birth and blood pressure at age 50 in Sweden? J Epidemiol Community Health 1997; 51: 14-8.

17. Valbø A. Smoking cessation in pregnancy. Effects of different intervention strategies. Nor J Epidemiol 1996; 6 (supplement 1).

18. Homan RK, Korenbrot CC. Explaining variation in birth outcomes of Medicaid eligible women with variation in the adequacy of prenatal support services. Medical Care 1998; 36 (2): 190-201.

19. Statistisk sentralbyrå. Levekårsundersøkelsen 1995. Oslo: SSB, 1997.

20. Blom S, Ritland A. Trang økonomi, men færre enn antatt opplever diskriminering; Samfunnsspeilet SSB 1997; 1: 1-17.

21. Skjeldestad FE, Borgan JK. Trends in induced abortions during the 12 years since legalization in Norway. Fam Plann Perspect 1994; 26: 73-6.

22. Stoltenberg C, Magnus P, Lie RT, Daltveit AK, Irgens LM. Birth defects and parental consanguinity in Norway. Am J Epidemiol 1997; 145: 1-10.

23. Oslo kommune, Byrådsavdelingen for finans. Oslo: Statistisk årbok for Oslo, 1997.

24. Magnus P, Berg K, Bjerkedal T. Association of parental consanguinity with decreased birth weight and increased rate of early death and congenital malformations. Clin Genet 1985; 28: 335-42.

25. Rognerud M. Røyking blant gravide kvinner i Norge - forslag til intervensjon. Nord Med 1993; 108: 228-9. 